\title{
REASONABLE OPPORTUNITY OF BEING HEARD UNDER ARTICLE 135(2) OF THE FEDERAL CONSTITUTION: A MIST OF OBSCURITY
}

\author{
Zukiferee Ibrahim ${ }^{1}$ \\ LLM Candidate, Faculty of Law and International Relations, \\ Universiti Sultan Zainal Abidin \\ (Email: zukiferee@umt.edu.my) \\ Abdul Majid Tahir Mohamed ${ }^{2}$ \\ Ph.D, Senior Lecturer, Faculty of Law and International Relations, \\ Universiti Sultan Zainal Abidin \\ (Email: amtmajid@unisza.edu.my)
}

Accepted date: $22-02-2019$

Published date: 10-07-2019

To cite this document: Ibrahim, Z., \& Mohamed, A. M. T. (2019). Reasonable Opportunity of Being Heard Under Article 135(2) of The Federal Constitution: A Mist of Obscurity. International Journal of Law, Government and Communication, 4(15), 113-120.

DOI: $10.35631 /$ ijlgc.4150012

\begin{abstract}
Article 135(2) of the Federal Constitution provides a right to be heard to any public servants in case of dismissal or reduction in rank by adopting the term 'reasonable opportunity of being heard'. Meanwhile, the Privy Council in Najar Singh's case in 1976 established a principle that the right to be heard under Article 135(2) does not imply the right to be heard orally. Despite this precedent, the term remains contentious in the courts of law as to whether the term includes the right to oral hearing. Recently, in 2018 the Federal Court in Vijayaroa's case inclines in favour of affording a right to be heard orally to an officer facing disciplinary proceedings. This article examined the scope of the term 'reasonable opportunity of being heard' under Article 135(2) and analysed the development of the cases law on the right to an oral hearing in disciplinary proceedings against public servants. The finding shows that the statutory term 'reasonable opportunity of being heard' has been interpreted inconsistently by the courts. Thus, the law on this issue remains unsettled.
\end{abstract}

Keywords: Constitutional Law, Administrative Law, Article 135(2) Federal Constitution, Right To Oral Hearing, Disciplinary Proceedings

\section{Introduction}

Article 135(2) of the Federal Constitution of Malaysia expressly provides the right to reasonable opportunity of being heard. This right is specifically bestowed to public servants facing disciplinary proceedings. In fact, this right is derived from the common law principle of natural 
justice. The right is one of the fundamental principles of the rule of natural justice, which embodies two important maxims: firstly, the right to be heard and secondly, the rule against bias ${ }^{1}$.

With regard to the first maxim i.e. the right to be heard, it shall be extensively discussed in the succeeding paragraphs since it is the main focus of this article. Meanwhile, briefly the rule against bias refers to the Latin maxim nemo judex in causa sua which means that no man can be a judge in his cause. It requires that any party who has pecuniary or personal interest not to be involved as the adjudicating body in the proceeding case. It is unnecessary to ask whether there is a reasonable suspicion or real likelihood of bias. ${ }^{2}$ However the Federal Court in Majlis Perbandaran Pualu Pinang v Syarikat Berkerjasama-sama Serbaguna Sungai Gelugor ${ }^{3}$ adopted the real danger of bias test. Nevertheless, in real practice of the disciplinary action of proceeding, the significant bias that needs to be observed is the personal bias.

Contextually, in Raja Abdul Malek Muzaffar Shah, ${ }^{4}$ Gopal Sri Ram JCA preferred the term "procedural fairness" instead of the rule of natural justice. Procedural fairness connotes that administrative bodies must adopt a fair procedure based on the facts of a particular case before them..$^{5}$ In the above case, the Court of Appeal held, inter alia, although the settled principle is that the right to be heard does not in all cases include a duty to afford an oral hearing, in some instances the failure or refusal to provide such a hearing could render a decision null and void. As such, the right to an oral hearing is an essential element of the right to be heard and must be thoroughly considered by administrative bodies conducting disciplinary proceedings against public servants. In addition, the right has been associated with the fundamental right to life of public servants. ${ }^{6}$

This writing shall examine the scope of the term 'reasonable opportunity of being heard' under Article 135(2); and analyse the development of the cases law on the right to an oral hearing in disciplinary proceedings against the public servants. Indeed, the right gives better safeguard to the affected public servants and also helps the government in reaching the right decisions since it may affect the credibility of the public administration at large. Since the focal point of this article is on the disciplinary proceedings of public servants, discussion on the application of the Employment Act 1955 is, therefore, beyond the scope of this article.

\section{Literature Review}

Romli et al ${ }^{7}$ discussed the rule of natural justice concerning the disciplinary proceeding in Police Department where it was submitted that the rule of natural justice is the minimum requirement in the decision-making process by the quasi-judicial such as the disciplinary authority. The literature also mentioned that in the deliverance of justice, the responsibility of the disciplinary authority is

\footnotetext{
1 'audi alteram partem' and 'nemo judex in causa sua' in Latin

${ }^{2}$ Wan Azlan Ahmad \& Nik Ahmad Kamal Nik Mahmod. Administrative Law in Malaysia, (Thomson, Sweet \& Maxwell Asia, 2006) 172.

3 [1999]3 MLJ 1

4 [1995] 1 AMR 855.

${ }^{5}$ Sridevi Thambapillay, 'Recent Developments in Judicial review of Administrative Action in Malaysia: A Shift from Grounds based on Common Law Principles to the Federal Constitution' in Persidangan Undang-undang Tuanku Ja'afar 2007 (Putrajaya, 21-22 August 2007) 276.

${ }^{6}$ Tan Tek Seng $v$ Suruhanjaya Perkhidmatan Pendidikan \& Anor [1996] 1 MLJ 261.

${ }^{7}$ Fariza Romli, Nuarrual Hilal Md Dahlan \& Rusniah Ahmad, 2012, Prinsip Keadilan Asasi Dalam Undang-Undang Berkaitan Prosedur Perbicaraan Tatatertib di Jabatan Polis: Suatu Analisa. UUM Journal of Legal Studies 3: $145-163$.
} 
not merely to submit to the statutory and regulations, but to ensure the rule of the natural justice is to be given to the relevant employee.

Another literature is written by Gan Ching Chuan ${ }^{8}$ where in discussing the issues of disciplinary procedure and its related application with the rule of natural justice and right to oral hearing he argued the right to a fair hearing is the sign quo non of modern administrative process that finds expression in some modern Constitutions as part of fundamental right. Whereas, V Ananta Raman (1993) in his article ${ }^{9}$ supported the suggestion that the application of audi alteram partem to be replaced by 'duty to act fairly' as a new common law concept in Malaysia.

Prof. Jain ${ }^{10}$ in his book on administrative law in Malaysia and Singapore thoroughly discussed on natural justice and its related issues and cases in a specific chapter. He viewed the right to an oral hearing as one of the natural justice principles. Natural justice according to him has no precise definition of its content. It has to be applied to the proceedings of a broad spectrum of decisionmaking bodies and inquiries like disciplinary proceedings against government servants. ${ }^{11}$

\section{Objectives}

This article will have the following objectives: firstly, to examine the scope of the term 'reasonable opportunity of being heard' under Article 135(2) of the Federal Constitution; and secondly, to analyse the development of the cases law on the right to an oral hearing in disciplinary proceedings against the public servants.

\section{Constitutional Protection Under Article 135(2)}

Article 135(2) has embodied the rule of natural justice that is developed from the English common law. It gives right to a 'reasonable opportunity of being heard' to a member of public service ${ }^{12}$ in cases of dismissal and reduction in rank. By this provision, public servants have to be accorded with such opportunity before an action of dismissal or reduction in rank can be meted out against them. However, Rusniah Ahmad ${ }^{13}$ pointed out the limitation of the constitutional protection in Article 135(2) that it applies only to cases with the purpose of dismissal or reduction in rank. Although disciplinary proceeding is purely administrative action, the rule of natural justice is still applicable as decided by Raja Azlan Shah in Ketua Pengarah Kastam v Ho Kwan Seng ${ }^{14}$ that:

The rule of natural justice that no man may be condemned unheard applies to every case where an individual is adversely affected by administrative action, no matter

\footnotetext{
${ }^{8}$ Gan, Ching Chuan, 2007, Disciplinary Proceedings Against Public Officers in Malaysia, Lexis Nexis, Singapore.

${ }^{9}$ V Ananta Raman, Natural Justice- The Malaysian Experience [1993] 3 MLJ i

${ }^{10}$ MP Jain, Administrative Law of Malaysia and Singapore, Third Edition, 1997, Malayan Law Journal, Kuala Lumpur

11 ibid at $\mathrm{p} 289$

${ }^{12}$ Article 132(1) specifies that services as members of public service comprised of (a) the armed forces, (b) the judicial and legal service, (c) the general public service of the Federation, (d) the police force, (e) the joint public services mentioned in Article 133, (g) the public service of each State and (h) the education service.

${ }^{13}$ Rusniah Ahmad, 2013. Applikasi Prinsip dan Kes-Kes Tatatertib, In Sistem Pengurusan Tatatertib di Tempat Kerja, pp. 68-101. Penerbit Universiti Utara Malaysia.
}

14 [1977] 2 MLJ 152 
whether it is labelled "judicial", "quasi-judicial", or "administrative" or whether or not the enabling statute makes provision for a hearing.

All members of public services except provided otherwise are subject to Public Officer (Conduct and Discipline) Regulations 1993. In this connection, Regulation 34(1) adopts the constitutional protection of reasonable opportunity of being heard in case of dismissal and reduction in rank of public servants. ${ }^{15}$

\section{Development of Case Law in Malaysia}

The interpretation of the court on the scope of the right to be heard varies in numerous cases and depends on the facts of each proceeding. The resolving issue is whether the right to be heard for a public servant in a disciplinary proceeding is limited to a written representation or extended to the right to an oral hearing? In Najar Singh $v$ Government of Malaysia,${ }^{16}$ the appeal to the Privy Council was on the ground that the appellant was not afforded a reasonable opportunity of being heard orally. Privy Council held that Regulation 27 of Chapter $\mathrm{D}^{17}$ is not to be interpreted as imposing an obligation to hear an officer orally. All that is needed that the affected public servant be given a full opportunity to state his case as pointed out by Viscount Dilhorne in his judgment. The Lordship further explained the meaning of the words 'being heard' in the Regulation in the following words:

In this passage which was cited by counsel on behalf of the appellant, the context shows that the words 'being heard' meant 'being heard orally' but this passage is no support for the proposition that unless there is an oral hearing, there is a denial of natural justice. Indeed, it points in the opposite direction.

The Supreme Court upheld the above principle in Ghazi Mohd Sawi v Mohd Haniff Omar, Ketua Polis Negara, Malaysia \& Anor ${ }^{18}$ and followed by the Federal Court in Lembaga Tatatertib Pekhidmatan Awam Hospital Besar Pulau Pinang \& Anor v Utra Badi Perumal. ${ }^{19}$ In fact, Utra Badi's was considered as another landmark case on the issue of the right to oral hearing where the Federal Court held that the right to be heard given by Article 135(2) of the Federal Court does not require that the member of the service facing the disciplinary charge be given an oral hearing.

\footnotetext{
${ }^{15}$ Regulation 34 (1) provides that an officer shall not be dismissed or reduced in rank unless he has been informed in writing of the grounds on which it is proposed to take action against him and been afforded a reasonable opportunity of being heard.

16 [1976] 1 MLJ 203 at p 205

${ }^{17}$ Regulation 27, Chapter D states: In all disciplinary proceedings under this Part no officer shall be dismissed or reduced in rank unless he has been informed in writing of the grounds on that it is proposed to take action against him and has been afforded a reasonable opportunity of being heard.

18 [1994] 2 CLJ 333. It was held inter alia that the word 'hearing' does not mean oral hearing and the right to be heard does not entail an obligation to hold an inquiry. The main consideration is that the person concerned should have a full opportunity of stating his case before being dismissed.

19 [2001] 2 CLJ 525. It was held in this case that the right to heard given by art 135(2) of the Constitution does not require that the person concerned be given an oral hearing and it could not be argued that the failure to give an oral hearing was a denial of justice.
} 
Meanwhile, in Vickneswary ${ }^{20}$ the same Federal Court held inter alia that from the provision of the general orders ${ }^{21}$ it is clear that it is never the intention of the legislators that the courts should step into the shoes of the disciplinary authority in deciding whether it was fair or not to the public officer to be granted the right to make oral representations. All these cases manifested that the apex court is relying on Najar Singh to extrapolate the principle that an oral hearing is not an essential element in natural justice.

In spite of the above judicial trend, the courts in certain occasions do not confine themselves with the principles in the above cases. For instance, the Court of Appeal in Ann Seng Wan v Suruhanjaya Polis Diraja Malaysia \& Anor, ${ }^{22}$ in interpreting the relevant provision on the right to be heard i.e O.26 of the General Order $1980^{23}$ inter alia ruled out that since there was no evidence to contradict the appellant's exculpatory statement, it would be justifiable to hold an oral hearing. In fact, prior to Utra Badi, the Court of Appeal in Raja Abdul Malek Shah b Raja Shahruzzaman v Setiausaha Suruhanjaya Pasukan Polis \& 2 Ors $^{24}$ despite citing the case of Najar Singh, went on to state that;

Nevertheless, the principle that the right to be heard is non-inclusive of a duty to afford on oral hearing does not mean that the failure or refusal to afford such hearing would render the decision reached safe and harmless from attack. Cases may arise where, in the light of peculiar facts, the failure to afford an oral hearing may result in the decision arrived at being a nullity or quashed. (see $R v$. Immigration Appeal Tribunal [1977] 1 WLR 795)

Meanwhile, in Yusof Sudin v Suruhanjaya Perkhidmatan Polis \& Anor, ${ }^{25}$ Zulkefli Makinuddin FCJ when allowing the appeal raised the view in his judgment that when there is a request by the public officer for an oral hearing after he had denied all the charges and exculpated himself by furnishing credible evidence in his representation letter, by virtue of O.26 (5) of the General Orders 1980, the officer should be accorded an oral hearing to satisfy the requirement of Article 135(2) of the Federal Constitution. It would become all the more necessary for the oral hearing or enquiry to be held if there was no evidence to contradict the public officer's exculpatory statement. In furtherance of that ruling, the learned judge held that the principle in the case Utra Badi and Vickneswary that states 'the right to heard given by Article 135(2) of the Federal Constitution does not require that the person concerned be given an oral hearing' does not apply to all cases.

A mist of obscurity continues after Yusuf Sudin's case when the same Federal Court in Kerajaan Malaysia \& Ors $v$ Tay Chai Huat ${ }^{26}$ upheld the principle in Utrabadi's case and Vickneswary's

\footnotetext{
${ }^{20}$ [2008] 6 CLJ 573 FC. The Federal Court ruled that it is clear that it is never the intention of the legislator in General Orders to give an officer under disciplinary action the right to give oral evidence.

${ }^{21}$ The court referred to S.24, 25 and 26 General Orders of the Public Officers (Conduct and Discipline) (Chapter D) General Orders 1980

22 [2002] 1 CLJ 493

${ }^{23}$ Order 26 General Order 1980 states the procedures of a disciplinary proceeding.

24 [1995] 1 AMR 855, COA

25 [2012] 1 CLJ 448 at p 450. In this case, the appellant prayed in his letter for an oral hearing by way of an inquiry to be given to him in the event his explanation was deemed insufficient to exculpate himself from the charges against him.
}

${ }^{26}$ [2012] 3 MLJ 149 at p 150. No request of oral hearing was made by the Respondent in this case. 
case. Mohd Ghazali FCJ in his judgment reiterated that the law is settled in cases of this genre. ${ }^{27}$ It was held that the right to be heard under Article 135 (2) did not require an oral hearing if the Disciplinary Authority considered that no further clarification was required, then the officer facing the disciplinary charges could not insist that a committee of inquiry be appointed. It is interesting to note that Mohd Ghazali Yusoff (FCJ) who delivered the majority judgment in this case, gave the dissenting judgment in Yusuf bin Sudin's case.

Later, the Court of Appeal in the case of Suruhanjaya Perkhidmatan Awam v Hjh Marina Hj Mustafa $^{28}$ referred to the case of Mat Ghaffar ${ }^{29}$ and held that it is settled principle that the right to be heard as enshrined in Art. 135 (2) of the Federal Constitution do not in all cases include the duty to afford an oral hearing.

The polemic remains further when in the case Abdul Ghani Che Mat v Pengerusi Suruhanjaya Pasukan Polis \& Ors, ${ }^{30}$ the Court of Appeal held that the audi alteram partem rule states that a decision cannot stand unless the person directly affected by it is given a fair opportunity whether he has the right to state his case as well as to know and answer the other side's case. It was held inter alia that; the right of hearing is a right to the minimum standard of procedural fairness and must not be confused with the question of whether the officer was guilty of the disciplinary offences. In carrying out the disciplinary procedure, natural justice requires that the disciplinary authority must employ means that justifies the end rather than the end justifying the means.

It must be noted that the most recent case on this issue is the case of Vijayarao a/l Sepermaniam $v$ Suruhanjaya Perkhidmatan Awam Malaysia, ${ }^{31}$ where the Court of Appeal held inter alia:

\begin{abstract}
Where there is a request by the public officer for an oral hearing after he had denied all the charges and appeared to have exculpated himself by furnishing credible evidence, the officer should be afforded an oral hearing. An oral hearing should be granted when there is a request and when the disciplinary authority is faced with two sets of facts, documents and evidence. The circumstances of each case must be fully considered before the court could conclude whether or not the right to an oral hearing has been rightly observed by the disciplinary authority.
\end{abstract}

On further appeal of Vijayarao's case, the Federal Court took the view that the law as currently adopted by the courts is more inclined in favour of affording a right to be heard orally to an officer facing disciplinary proceedings if there is a request made by him to the disciplinary authority.

\footnotetext{
27 It was highlighted several decisions which were decided prior to Utra Badi and Vickneswary like Hjh Halimatussaadiah bte Hj Kamaruddin v Public Services Commission, Malaysia \& Anor [1994] 3 MLJ 61, Ghazi bin Mohd Sawi v Mohd Hanif bin Omar, Ketua Polis Negara, Malaysia \& Anor [1994] 2 MLJ 114 [1994] 2 MLJ 114, Zainal bin Hashim v Government of Malaysia [1979] 2 MLJ 276 and Najar Singh v Government of Malaysia \& Anor [1974] 1 MLJ 138.

${ }^{28}$ [2015] 4 CLJ 312. The Court held that the right to a reasonable opportunity of being heard under art. 135(2) is not synonymous with a right to an oral hearing, that should be granted according to the circumstances of the case at $\mathrm{p} 312$.

${ }^{29}$ [2008] 1 CLJ 773. In this case, the Court of Appeal applied the principle in Ang Wan Seng. It was held that it was incumbent upon the Disciplinary Authority to initially consider the charges made against the public officer and to determine whether in the light of representation made by him an oral hearing was warranted.

30 [2017] 3 CLJ 399 at p 400.

${ }^{31}$ [2017] 4 CLJ 451 at $\mathrm{p} 452$. This case is on appeal to Federal Court.
} 


\section{Analysis}

Based on the cases highlighted before, it is propounded that the interpretation of courts on the term 'reasonable opportunity of being heard' can be regarded as liberal or restricted in nature. In most cases, the court will follow the previous judicial precedents in Najar Singh assiduously and thus regarded the law on this issue has been settled. For instance, in Utra Badi's case, the Federal Court Abdul Malek FCJ stated affirmatively that:

There should not be any more lingering doubt as to what the phrase 'right to be heard' or 'opportunity of being heard' mean at common law or in the statute, and it must be accepted that the issue has been settled, as well as can be on the authorities cited above. Therefore, this points is cadit question. '..

This restricted approach can also be seen in Tay Chai Huat's case when the Federal Court reminded that the use of precedent is an indispensable foundation on which to decide what is the law and how it should be applied in individual cases. Mohd Ghazali FCJ delivering the judgment of the court ruled that:

Utra Badi and Vickeswary are decisions that settled the law in cases of this genre with finality. I would think that this court would have need to hesitate long before distinguishing Utra Badi and Vickneswary on inadequate grounds....

In the other cases, the courts stood in a liberal way on the interpretation of the term 'reasonable opportunity of being heard'. In support of this, we may refer to the case Yusuf Sudin. The court of the view that if the principle laid down in Utra Badi's case is to apply to all cases without exceptions, it would appear no oral hearing may be claimed in disciplinary proceedings. Thus, this will vitiate the significance, purpose and implications of Article 135(2) as a constitutional right.

The liberal interpretation may be also contributed by the attitude of the court incorporating the right to be heard in Article 135(2) with Article 8, that all persons are equal before the law and have equal protection of it and, Article 5, that no person shall be deprived of life or personal liberty save in accordance with law. According to Choo Chin Thye, ${ }^{32}$ the constitutional notion of equality and its related notions of rejecting arbitrariness and instituting of fairness housed in our Article 8 stand on a far superior footing compared to English common law principles of equality since those notions are enshrined in the supreme law of Malaysia. The Court of Appeal manifested this approach in Tan Tek Seng's case ${ }^{33}$ where the court raised the observance of procedural fairness that is connected to a fundamental right like the right to life in Article 5, should be interpreted to include the rights to livelihood. Long before that, in Ong Ah Chuan v Public Prosecutor and Another, ${ }^{34}$ Lord Diplock said the reference to 'law' or 'protection of law' referred to a system of law, which incorporated those fundamental rules of natural justice and formed part of common law that was in operation in Malaysia and Singapore.

Therefore, it can be said that the court's decisions, in determining whether the term "reasonable opportunity of being heard" includes the right to an oral hearing or otherwise, are inconsistent. This, at least in part, presents a great difficulty in defining the true intent behind the protective provisions of the Constitution and the rules governing disciplinary action.

\footnotetext{
${ }^{32}$ Choo Chin Thye, The Role of Article 8 of the Federal Constitution in the Judicial Review of Public Law in Malaysia, Malayan Law Journal, civ [2002] 3 MLJ

${ }^{33}$ Tan Tek Seng $v$ Suruhanjaya Perkhidmatan Pendidikan \& Anor [1996] 1 MLJ 261

${ }^{34}$ [1980] 1 LNS 181; [1981] 1 MLJ 64 in Yusuf Sudin's case at p.458
} 
As a result, the terms "reasonable opportunity of being heard" in Article 135 (2) of the Federal Constitution has continuously generated a wealth of case law $^{35}$ until the issue is ultimately settled by the court or the legislature.

\section{Conclusion}

The above discussion shows that despite constitutional protection under Article 135(2) to the public servants in Malaysia in case of dismissal or reduction in rank, the position of oral hearing remains a contentious matter as envisaged by the case of Yusuf Sudin and Tay Chai Huat. This is because the interpretation of "reasonable opportunity of being heard" continues to be contentious. Unfortunately, though the constitutional provision under Article 135(2) was adopted in the Public Officer (Conduct and Discipline) Regulations 1993, the same Regulation limits the 'reasonable opportunity of being heard' merely to a written representation. However, it must be noted that a mere regulation cannot restrict the scope of constitutional term of 'reasonable opportunity', and it is for the court in exercising its real function of interpreting the provision of the Constitution to determine the real question of whether an oral hearing is part of the 'reasonable opportunity of being heard' or not. Though the judicial approaches adopted by the court are inconsistent, it is really hoped that the latest decision of the Federal Court in Vijayaroa's case would be able to resolve and put the contentious issue related to Article 135(2) into rest.

\section{References}

Choo Chin Thye, The Role of Article 8 of the Federal Constitution in the Judicial Review of Public Law in Malaysia, Malayan Law Journal, civ [2002] 3 MLJ

Fariza Romli, Nuarrual Hilal Md Dahlan \& Rusniah Ahmad. 2012. Prinsip Keadilan Asasi Dalam Undang-Undang Berkaitan Prosedur Perbicaraan Tatatertib di Jabatan Polis: Suatu Analisa. UUM Journal of Legal Studies 3: 145-163.

Federal Constitution. 2017. Malaysia: The Commissioner of Law Revision.

Gan Ching Chuan. 2007. Disciplinary Proceedings Against Public Officers in Malaysia. Singapore: Lexis Nexis.

MP Jain 1997, Administrative Law of Malaysia and Singapore, Third Edition, Malayan Law Journal, Kuala Lumpur.

S. Jayakumar, Protection For Civil Servants: The Scope of Article 135(1) And (2) of The Malaysian Constitution As Developed Through The Cases, The Malayan Law Journal, November 1969 p liv-lxii

Shad Saleem Faruqi, 2011, Safeguards for Public Servants, http://www.Malaysianbar.org.my [19 October 2011]

Sridevi Thambapillay, 'Recent Developments in Judicial review of Administrative Action in Malaysia: A Shift from Grounds based on Common Law Principles to the Federal Constitution' in Persidangan Undang-undang Tuanku Ja'afar 2007 (Putrajaya, 21-22 August 2007)

V Ananta Raman, Natural Justice- The Malaysian Experience, Malayan Law Journal [1993] 3 MLJ i

\footnotetext{
${ }^{35}$ Shad Saleem Faruqi, 2011, Safeguards for Public Servants, http://www.Malaysianbar.org.my [19 October 2011].
} 